\title{
Cross-amplification of nonspecific microsatellites markers: a useful tool to study endangered/ vulnerable species of southern Andes deer
}

\author{
J.C. Marín ${ }^{1}$, P. Orozco-terWengel ${ }^{2}$, K. Romero ${ }^{1}$, J.P. Vásquez ${ }^{1}$, V. Varas ${ }^{3}$ \\ and J.A. Vianna ${ }^{4}$ \\ ${ }^{1}$ Laboratory of Genomic and Biodiversity, \\ Department of Basic Sciences, University of Bío-Bío, Chillán, Chile \\ ${ }^{2}$ School of Biosciences, Cardiff University, Cardiff, Wales, UK \\ ${ }^{3}$ Institute of Environmental Science and Evolution, \\ Faculty of Sciences, Austral University of Chile, Valdivia, Chile \\ ${ }^{4}$ Departament of Ecosystem and Environment, \\ Pontifical Catholic University of Chile, Santiago, Chile \\ Corresponding author: J.C. Marín \\ E-mail: jcmarin@ubiobio.cl
}

Genet. Mol. Res. 13 (2): 3193-3200 (2014)

Received June 5, 2013

Accepted January 28, 2014

Published April 25, 2014

DOI http://dx.doi.org/10.4238/2014.April.25.4

\begin{abstract}
Thirty-nine microsatellite loci that are highly conserved in red deer, sika deer, reindeer, Soay sheep, and other artiodactyls were tested in two vulnerable and endangered Neotropical deer (pudu: Pudu puda and huemul: Hippocamelus bisulcus) with the aim of producing a standardized set of markers that can be used successfully in noninvasive samples from these species. We also compared these nonspecific loci against eight polymorphic loci that were recently developed for huemul to determine whether the nonspecific markers could reflect the huemul's genetic variation that was observed with the specific loci. We identified 10 suitable loci, six of which constitute a standardized set for the two species and can be used to identify them in the absence of phenotypic data. The expected heterozygosity per locus for the panel of
\end{abstract}


six loci ranged from 0.461 to 0.889 (average 0.665 ), and the maximum probability of identity value was $6.9 \times 10^{-6}$ and $3.2 \times 10^{-4}$ in pudu and huemul, respectively. This set of loci has potential applications in evolutionary, ecological, forensic, and conservation studies in pudu and huemul.

Key words: Cervidae; Huemul; Pudu; Short tandem repeat; Nonspecific microsatellites; Species genetic determination

\section{INTRODUCTION}

Microsatellite markers are highly polymorphic nuclear DNA loci, which carry valuable information about species' evolutionary history. Although these markers have been isolated for multiple species, it is typical to isolate new markers for genetically undescribed taxa. This is a costly and time-consuming process. The cross-amplification of nonspecific markers (i.e., markers designed for a different species but can be amplified in a taxon of interest) may reduce genotyping costs, allowing the development of population genetic studies in otherwise uncharacterized taxa. A high rate of cross-amplification has already been reported for many animal species, such as tortoises (Orozco-terWengel et al., 2013), apes (Deka et al., 1994), canids (Fontoura-Rodrigues et al., 2008), and ungulates (Leite et al., 2007; Shafer et al., 2012). The rate of cross-amplification in Artiodactyla is surprisingly high, even between different families (e.g., Cervidae and Bovidae), indicating high genome similarity (Leite et al., 2007).

For conservation biology, genetic data can be a useful tool to determine a specie's threat status. For this purpose, the successful amplification of microsatellite markers from noninvasive samples (e.g., faeces) is of utmost importance for species genetic characterization when the taxa are elusive, rare, or cannot be approached for invasive sample collection (e.g., blood). The cross-amplification of microsatellites has been shown using canid fecal samples (Fontoura-Rodrigues et al., 2008) and invasive samples in deer (Cosse et al., 2007; Leite et al., 2007). In the case of pudu and huemul, there is no information about the cross-amplification of polymorphic loci. Only eight microsatellites have been reported in huemul (Shafer et al., 2012), and none have been reported for pudu.

Hippocamelus bisulcus (huemul) is the world's southernmost large deer species, and it inhabits southern Chile and Argentina's Andean forest and Patagonian fjords. Huemul is an endangered species (IUCN, 2012) mostly due to habitat loss and population fragmentation. This is exacerbated by the consequent population isolation, poaching, and disturbance and predation by domestic dogs. This condition has led to a contraction of its historic distribution (34 to $54^{\circ} \mathrm{S}$ latitude) over the last 200 years. Currently, a population of 1000-2000 extant huemul inhabits the far south of Chile and Argentina (Serret, 1992) with the exception of a single isolated population that occurs between 36 and $37^{\circ} \mathrm{S}$ (central Chile) at Nevados de Chillán (Povilitis, 1998). Nevados de Chillán is likely a refugial population whose genetic richness is yet unknown.

Pudu puda (pudu) is one of the smallest deer in the world, with adults reaching just $40 \mathrm{~cm}$ in height and weighing less than $10 \mathrm{~kg}$ (Silva-Rodríguez et al., 2010). Pudus are solitary, humid forest dwellers that are endemic to the Andean lowlands (Wemmer, 1998). Their geographical distribution ranges from 36 to $49^{\circ} \mathrm{S}$ in Chile and from 39 to $43^{\circ} \mathrm{S}$ in Argentina 
(Meier and Merino, 2007), where approximately 10,000 animals live (Wemmer, 1998). Alterations in the habitat (the replacement of native trees and shrubs by plantations of introduced trees), death from feral dogs, frequent poaching, and introduction of non-native deer species (such as red deer, fallow deer, and roe deer) are the main causes of the steady decline of pudu's wild populations (Hershkovitz, 1982). The pudu is categorized as vulnerable on the IUCN Red List (IUCN, 2012), and it is included in Appendix I of the Convention on International Trade of Endangered Species of Wild Fauna and Flora.

This study aimed to test a panel of microsatellites that were isolated in deer, sika deer, reindeer, Soay sheep, and other artiodactyls (Slate et al., 1998; Wilson and Strobeck, 1999; Cronin et al., 2006) in pudu and huemul and to compare nonspecific microsatellite loci against huemul-specific loci. This was performed in order to identify loci that i) successfully amplify, ii) are polymorphic in both species, and iii) generate short amplification products ( $<350 \mathrm{bp}$ ), facilitating their use in DNA that is obtained from feces and hairs. We evaluated 39 microsatellites with forward primers containing a 5'-M13 tail (Boutin-Ganache et al., 2001). Both species are partially co-distributed in the temperate forests in Chile and Argentina and are lesser-known South American deer. Therefore, it is important to produce a standardized set of markers that can be successfully used in noninvasive samples from these species.

\section{MATERIAL AND METHODS}

Huemul and pudu samples were collected throughout their current distribution range (Table 1) following guidelines of the American Society of Mammalogists (Sikes et al., 2011). DNA samples were obtained using three methods: 1) skin samples from adults obtained with biopsy darts (Dan-Inject Biopsy Needle, Børkop, Denmark), 2) muscle or skin tissue from dead animals found during field work, and 3) blood samples following chemical immobilization from wild-caught freeranging individuals that were sent to wildlife rehabilitation centers.

\begin{tabular}{|c|c|c|}
\hline Location, Country & Geographic position & Samples \\
\hline Pudu puda & & $\mathrm{N}=44$ \\
\hline Hualqui, Región del Bío-Bío, Chile & $36^{\circ} 57^{\prime} 10^{\prime \prime} \mathrm{S}, 72^{\circ} 55^{\prime} 20^{\prime \prime} \mathrm{W}$ & 1 \\
\hline Coihueco, Región del Bío-Bío, Chile & $36^{\circ} 38^{\prime} 00^{\prime \prime} \mathrm{S}, 71^{\circ} 45^{\prime} 50^{\prime \prime} \mathrm{W}$ & 2 \\
\hline Pucón, Villarrica National Park, Región de la Araucanía, Chile & $39^{\circ} 15^{\prime} 50^{\prime \prime} \mathrm{S}, 71^{\circ} 54^{\prime} 00^{\prime \prime} \mathrm{W}$ & 6 \\
\hline Loncoche, Región de la Araucanía, Chile & $39^{\circ} 22^{\prime} 00^{\prime \prime} \mathrm{S}, 72^{\circ} 40^{\prime} 60^{\prime \prime} \mathrm{W}$ & 2 \\
\hline Valdiva, Región de los Ríos, Chile & $39^{\circ} 49^{\prime} 10^{\prime \prime} \mathrm{S}, 73^{\circ} 11^{\prime} 50^{\prime \prime} \mathrm{W}$ & 23 \\
\hline Puyehue, Puyehue National Park, Región de los Ríos, Chile & $40^{\circ} 43^{\prime} 20^{\prime \prime} \mathrm{S}, 72^{\circ} 19^{\prime} 40^{\prime \prime} \mathrm{W}$ & 4 \\
\hline Chiloé, Chiloé National Park, Región de los Lagos, Chile & $42^{\circ} 37^{\prime} 30^{\prime \prime} \mathrm{S}, 74^{\circ} 06^{\prime} 00^{\prime \prime} \mathrm{W}$ & 6 \\
\hline Hippocamelus bisulcus & & $\mathrm{N}=55$ \\
\hline Río Simpson National Reserve, Región de Aysen, Chile & $45^{\circ} 36^{\prime} 07^{\prime \prime} \mathrm{S}, 72^{\circ} 12^{\prime} 52^{\prime \prime} \mathrm{W}$ & 5 \\
\hline Cerro Castillo, National Reserve, Región de Aysen, Chile & $45^{\circ} 58^{\prime} 55^{\prime \prime} \mathrm{S}, 71^{\circ} 55^{\prime} 43^{\prime \prime} \mathrm{W}$ & 7 \\
\hline Lago Cochrane National Reserve, Región de Aysen, Chile & $47^{\circ} 13^{\prime} 06^{\prime \prime} \mathrm{S}, 72^{\circ} 29^{\prime} 46^{\prime \prime} \mathrm{W}$ & 12 \\
\hline Tortel cove, Región de Aysen, Chile & $47^{\circ} 49^{\prime} 51^{\prime \prime} \mathrm{S}, 73^{\circ} 18^{\prime} 23^{\prime \prime} \mathrm{W}$ & 5 \\
\hline Bravo river, Región de Aysen, Chile & $48^{\circ} 02^{\prime} 37^{\prime \prime} \mathrm{S}, 73^{\circ} 01^{\prime} 04^{\prime \prime} \mathrm{W}$ & 5 \\
\hline Bernado lagoon, B. O’Higgins National Park, Región de Aysen, Chile & $48^{\circ} 35^{\prime} 33^{\prime \prime} \mathrm{S}, 73^{\circ} 54^{\prime} 28^{\prime \prime} \mathrm{W}$ & 13 \\
\hline Torres del Paine National Park, Región de Magallanes, Chile & $51^{\circ} 07^{\prime} 43^{\prime \prime} \mathrm{S}, 73^{\circ} 07^{\prime} 07^{\prime \prime} \mathrm{W}$ & 8 \\
\hline
\end{tabular}

Genomic DNA was extracted from blood or tissue samples with a phenol/chloroform protocol and from fresh faeces using the QIAamp DNA Stool Mini Kit (QIAGEN, Valencia, 
CA, USA). Thirty-nine autosomal dinucleotide microsatellite loci were tested in both species (Table 2). After establishing the polymerase chain reaction (PCR) product size, the primers where labelled with FAM, NED, or HEX fluorescent dyes for multiplexing. PCRs were performed in $10 \mu \mathrm{L}$ containing $0.2 \mathrm{mM}$ of each dNTP, $2 \mathrm{mM} \mathrm{MgCl}_{2}, 0.2 \mu \mathrm{M}$ reverse primer and fluorescent M13 primer, $0.013 \mu \mathrm{M}$ forward primer, $0.25 \mathrm{U}$ Taq polymerase (Invitrogen), and 10-50 ng DNA. The conditions were the same for all loci to maximize standardization. PCR profiles included initial denaturing at $94^{\circ} \mathrm{C}$ for $3 \mathrm{~min}$; 10 touchdown cycles of $94^{\circ} \mathrm{C}$ for $45 \mathrm{~s}$, annealing at $60^{\circ}-50^{\circ} \mathrm{C}\left(-1^{\circ} \mathrm{C} /\right.$ cycle $)$ for $45 \mathrm{~s}$, and $72^{\circ} \mathrm{C}$ for $1 \mathrm{~min} 30 \mathrm{~s} ; 30$ additional cycles with constant annealing temperature at $50^{\circ} \mathrm{C}$; and final extension at $72^{\circ} \mathrm{C}$ for $30 \mathrm{~min}$. PCR products were genotyped using an ABI Prism 377 or 3100 semi-automated DNA analyzer.

\begin{tabular}{|c|c|c|c|c|c|}
\hline \multirow[t]{2}{*}{ Locus } & \multirow[t]{2}{*}{ Reference } & \multicolumn{2}{|c|}{ Pudu puda } & \multicolumn{2}{|c|}{ Hippocamelus bisulcus } \\
\hline & & No. of alleles & Observed size (bp) & No. of alleles & Observed size (bp) \\
\hline BBJ2 & Wilson and Strobeck (1999) & 6 & $185-195$ & 4 & $187-195$ \\
\hline BBJ11 & Wilson and Strobeck (1999) & 5 & $144-152$ & 2 & $195-201$ \\
\hline BBJ24 & Wilson and Strobeck (1999) & 2 & $276-278$ & $*$ & - \\
\hline RT7 & Wilson et al. (1997) & 2 & $153-155$ & 2 & $223-225$ \\
\hline RT5 & Wilson et al. (1997) & $*$ & - & 6 & $184-212$ \\
\hline RT10 & Wilson et al. (1997) & * & - & $*$ & - \\
\hline RT13 & Wilson et al. (1997) & $*$ & - & 2 & $300-302$ \\
\hline RT27 & Wilson et al. (1997) & 5 & $172-182$ & 6 & $194-204$ \\
\hline RT30 & Wilson et al. (1997) & 16 & $187-223$ & 2 & $212-214$ \\
\hline BM121 & Bishop et al. (1994) & $*$ & - & 1 & 152 \\
\hline BM848 & Bishop et al. (1994) & $*$ & - & 1 & 227 \\
\hline BM6506 & Bishop et al. (1994) & 11 & $205-229$ & 3 & $205-213$ \\
\hline BM6438 & Bishop et al. (1994) & 1 & 270 & 2 & $271-273$ \\
\hline BM1225 & Bishop et al. (1994) & 1 & 264 & 2 & $231-235$ \\
\hline BM203 & Bishop et al. (1994) & 10 & $244-264$ & 4 & $234-240$ \\
\hline BM4025 & Bishop et al. (1994) & $*$ & - & 1 & 146 \\
\hline BM4107 & Bishop et al. (1994) & $*$ & - & 1 & 185 \\
\hline ABS012 & Bishop et al. (1994) & 1 & 150 & $*$ & - \\
\hline BL25 & Bishop et al. (1994) & 1 & 196 & 5 & $194-202$ \\
\hline ABS012 & Bishop et al. (1994) & 1 & 150 & $*$ & - \\
\hline BL6 & Grosz et al. (1997) & $*$ & - & 2 & 198 \\
\hline Cervid 1 & DeWoody et al. (1995) & * & - & $*$ & - \\
\hline Cervid 2 & DeWoody et al. (1995) & $*$ & - & $*$ & - \\
\hline Cervid 3 & DeWoody et al. (1995) & 2 & $330-332$ & $*$ & - \\
\hline Cervid 14 & DeWoody et al. (1995) & 8 & $226-262$ & 7 & $202-240$ \\
\hline INRA011 & Vaiman et al. (1992) & $*$ & - & 2 & $203-205$ \\
\hline INRA 107 & Vaiman et al. (1992) & * & - & $*$ & - \\
\hline INRA 121 & Vaiman et al. (1992) & $*$ & - & $*$ & - \\
\hline NVRT 16 & Røed and Midthjell (1998) & 1 & 220 & $*$ & - \\
\hline NVRT 22 & Røed and Midthjell (1998) & 2 & $166-168$ & $*$ & - \\
\hline NVHRT 30 & Røed and Midthjell (1998) & $*$ & - & $*$ & - \\
\hline $\mathrm{N}$ & Jones et al. (2000) & 9 & $337-383$ & 7 & $299-345$ \\
\hline Q & Jones et al. (2000) & $*$ & - & 2 & $271-275$ \\
\hline BDC01 & Oliveira et al. (2008) & $*$ & - & $*$ & - \\
\hline $\mathrm{BDC} 04$ & Oliveira et al. (2008) & $*$ & - & $*$ & - \\
\hline BDC15 & Oliveira et al. (2008) & 2 & $150-152$ & $*$ & - \\
\hline $\mathrm{BDC} 28$ & Oliveira et al. (2008) & $*$ & - & $*$ & - \\
\hline BDC65 & Oliveira et al. (2008) & 1 & 148 & 1 & 147 \\
\hline CSS043 & Moore et al. (1994) & * & - & $*$ & - \\
\hline
\end{tabular}

*No amplification.

For each sampled population of the two focal species, we tested the Hardy-Weinberg (HW) equilibrium, linkage disequilibrium (LD), and probability of identity (PI) using Ge- 
nAlEx 6.4.1 (Peakall and Smouse, 2006). Finaly, in huemul, we also compared the amplification results of seven nonspecific microsatellite loci against eight polymorphic loci that were recently developed for the species (Shafer et al., 2012).

\section{RESULTS AND DISCUSSION}

We initially tested 10 individuals of each species from different localities, and markers with adequate PCR product sizes were screened in 44 pudu samples and 55 huemul samples (Table 1). This screening process yielded six loci that showed all of the desired characteristics (Table 3). Four other microsatellites (two for each species) were found to be potentially useful for population studies despite not meeting all the target criteria for all species. Loci RT30 and BBJ11 presented the highest levels of allelic richness in pudu $\left(\mathrm{A}=16, H_{\mathrm{E}}=0.904\right.$, and $H_{\mathrm{O}}=$ 0.487 and $\mathrm{A}=5, H_{\mathrm{E}}=0.692$, and $H_{\mathrm{O}}=0.571$, respectively) but low polymorphism in huemul. The RT5 locus presented moderate levels of allelic richness in huemul $\left(\mathrm{A}=6 ; H_{\mathrm{E}}=0.736 ; H_{\mathrm{O}}\right.$ $=0.181$ ), but it was not amplified in pudu. Finally, locus BL25 was monomorphic in pudu and moderately polymorphic in huemul (Table 2). Consequently, we suggest that although these loci may not be ideal for studies where non-invasive samples from both species are analyzed simultaneously, they should be considered for species-specific analyses (Table 2).

\begin{tabular}{|c|c|c|c|c|c|c|c|c|c|c|}
\hline \multirow[t]{2}{*}{ Locus } & \multicolumn{5}{|c|}{ Pudu puda } & \multicolumn{5}{|c|}{ Hippocamelus bisulcus } \\
\hline & $\mathrm{N}$ & A & Size (bp) & $H_{\mathrm{E}}$ & $\overline{H_{\mathrm{O}}}$ & $\mathrm{N}$ & $\mathrm{A}$ & Size (bp) & $H_{\mathrm{E}}$ & $H_{\mathrm{o}}$ \\
\hline$\overline{\mathrm{BBJ} 2}$ & 44 & 6 & $185-195$ & $0.684^{* *}$ & 0.651 & 52 & 4 & $187-195$ & $0.505^{*}$ & 0.615 \\
\hline RT27 & 14 & 5 & $172-182$ & $0.889^{\text {ns }}$ & 0.400 & 54 & 6 & $194-204$ & $0.552 * *$ & 0.333 \\
\hline BM6506 & 42 & 11 & $205-229$ & $0.812^{\mathrm{ns}}$ & 0.785 & 26 & 3 & $205-213$ & $0.645^{* *}$ & 0.080 \\
\hline BM203 & 30 & 10 & $244-264$ & $0.876^{* *}$ & 0.620 & 55 & 4 & $234-240$ & $0.522^{\mathrm{ns}}$ & 0.436 \\
\hline Cervid 14 & 24 & 8 & $226-262$ & $0.546^{*}$ & 0.500 & 44 & 7 & $202-240$ & $0.688 * *$ & 0.250 \\
\hline $\mathrm{N}$ & 39 & 9 & $337-383$ & $0.739^{*}$ & 0.717 & 49 & 7 & $299-345$ & $0.461 * *$ & 0.142 \\
\hline
\end{tabular}

$\mathrm{N}=$ sample size; $\mathrm{A}=$ number of observed alleles; size range of the PCR products (Size), $H_{\mathrm{F}}=$ expected heterozygosity; $H_{\mathrm{O}}=$ observed heterozygosity, for microsatellite loci in two southern Andes deer. Asterisks in the $H_{\mathrm{E}}$ column indicate loci that exhibited departure from Hardy-Weinberg equilibrium $(\mathrm{P}<0.05)$ in at least one population of the indicated species $(\mathrm{ns}=$ not significant; $* \mathrm{P}<0.05 ; * * \mathrm{P}<0.001)$.

No significant LD was detected among any of the pairwise comparisons of loci in either of the two species. This supports the hypothesis that these loci segregate independently in each species' genome. Three loci presented a significant deviation from HW equilibrium after Bonferroni's correction (pudu: RT27 and BM6506; huemul: BM203), but it is likely that this observation reflects an underlying pattern of population structure that was not yet assessed in these samples. The estimated PI values in the analysis of the six loci simultaneously were $6.9 \times 10^{-6}$ in pudu and $3.2 \times 10^{-4}$ in huemul (Figure 1), indicating a high probability of successful individual identification using these markers. The mean number of alelles per locus was $8.87 \pm 1.67$ and $5.25 \pm 1.64$, and the mean expected heterozygosity was 0.759 and 0.570 in pudu and huemul, respectively. The average expected heterozygosity for all six loci was 0.665 , and the mean polymorphism information content value was 0.605 . No significant differences in expected heterozygosity were found between the two species using the six loci (Fisher's exact test $\mathrm{P}=1$ ). 


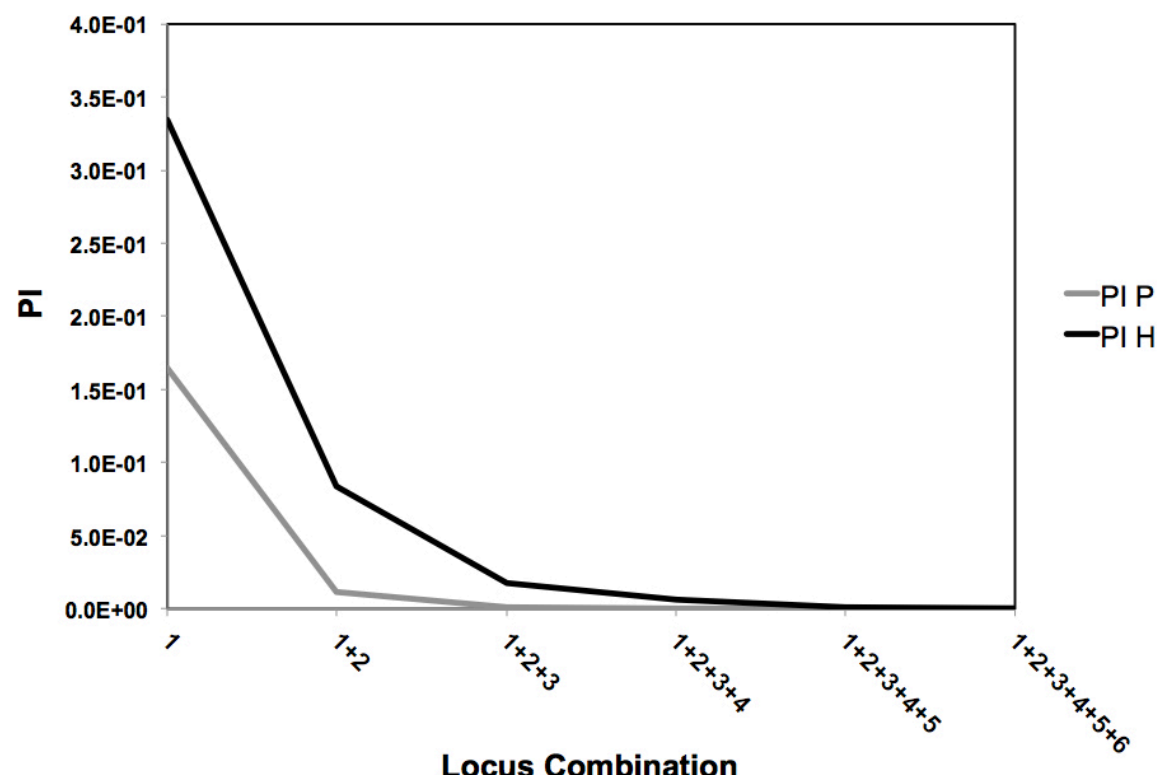

Figure 1. Probability of identity (PI) in Pudu puda (PI P) and Hippocamelus bisulcus (PI H) using the selected panel of six microsatellite loci.

Additionally, we compared eight huemul-specific microsatellites against seven loci that were developed in other ungulates. The goal of this comparison was to determine whether the markers that were developed in other ungulates presented similar levels of polymorsphism as the huemul-specific markers. Interestingly, these two sets of loci did not differ statistically in terms of expected heterozygosity (Welch $t$-test $\mathrm{P}=0.9$ ). Consequently, we suggest that these seven markers can be used to complement the eight huemul-specific loci to increase the marker set that is available for this species.

The markers that were identified here show great potential for population and evolutionary studies of Neotropical deer, including the use of noninvasive sampling and comparative analyses across species. This set of primers proved to have sufficient levels of polymorphism and heterozygosity to differentiate between pudu and huemul on the basis of the alleles that were found in each species. Furthermore, the availability of a common set of polymorphic markers in these species allows testing of the population genetic parameters that are required to establish the conservation status of natural populations without needing to develop species-specific markers. We also showed that the differences in allele frequency distributions between these markers have value for forensic cases when species determination is necessary in the absence of phenotypic data (e.g., Marín et al., 2009). These microsatellite markers will be useful for resolving conservation problems related to management programs for these southern Andes deer.

\section{ACKNOWLEDGMENTS}

Research funded by FONDECYT grant \#11080098, the DID Universidad del Bío-Bío (grant \#082409 1/R), and postdoctoral grant \#3110187. Special thanks to Comité Nacional 
Pro Defensa de la Fauna y Flora (CODEFF), Nomades Outdoor Service, Forestal Celco S.A., Centro de Estudios del Cuaternario Fuego-Patagonia y Antartica (CEQUA), and Wildlife Conservation Society. We thank the Servicio Agrícola y Ganadero (SAG, permit \#2002, 2008 and permit \#5748, 2008) and the Corporación Nacional Forestal (CONAF, permit \#21/08, 2008). We also thank Paulo Corti and Mauricio Soto (Universidad Austral de Chile), Marcelo Fuentes-Hurtado (Universidad Andrés Bello), and Rodrigo López (AUMEN ORG) for collecting samples. We would like to thank David Stanton (Cardiff University) for coments on preliminary versions of the manuscript.

\section{REFERENCES}

Bishop MD, Kappes SM, Keele JW, Stone RT, et al. (1994). A genetic linkage map for cattle. Genetics 136: 619-639. Boutin-Ganache I, Raposo M, Raymond M and Deschepper CF (2001). M13-tailed primers improve the readability and usability of microsatellite analyses performed with two different allele-sizing methods. Biotechniques 31: 24-6, 28.

Cosse M, González S and Maldonado JE (2007). Cross-amplification tests of ungulate primers in the endangered Neotropical pampas deer (Ozotoceros bezoarticus). Genet. Mol. Res. 6: 1118-1122.

Cronin MA, Macneil MD and Patton JC (2006). Mitochondrial DNA and microsatellite DNA variation in domestic reindeer (Rangifer tarandus tarandus) and relationships with wild caribou (Rangifer tarandus granti, Rangifer tarandus groenlandicus, and Rangifer tarandus caribou). J. Hered. 97: 525-530.

Deka R, Shriver MD, Yu LM, Jin L, et al. (1994). Conservation of human chromosome 13 polymorphic microsatellite (CA) n repeats in chimpanzees. Genomics 22: 226-230.

DeWoody JA, Honeycutt RL and Skow LC (1995). Microsatellite markers in white-tailed deer. J. Hered. 86: 317-319.

Fontoura-Rodrigues ML, Lima-Rosa CA, Tchaicka L, Valdez FP, et al. (2008). Cross-amplification and characterization of 13 tetranucleotide microsatellites in multiple species of Neotropical canids. Mol. Ecol. Resour. 8: 898-900.

Grosz MD, Solinas-Toldo S, Stone RT, Kappes SM, et al. (1997). Chromosomal localization of six bovine microsatellite markers. Anim. Genet. 28: 39-40.

Hershkovitz P (1982). Neotropical deer (Cervidae): Part 1. Pudus, genus Pudu Gray. Fieldiana Zool. 11: 1-86.

IUCN (2012). IUCN Red List of Threatened Species. Version 2012.2 Available at [www.iucnredlist.org]. Accessed October 17, 2012.

Jones KC, Levine KF and Banks JD (2000). DNA-based genetic markers in black-tailed and mule deer for forensic applications. Calif. Fish Game 86: 115-126.

Leite KC, Collevatti RG, Menegasso TR, Tomas WM, et al. (2007). Transferability of microsatellite loci from Cervidae species to the endangered Brazilian marsh deer, Blastocerus dichotomus. Genet. Mol. Res. 6: 325-330.

Marín JC, Saucedo CE, Corti P and Gonzalez BA (2009). Application of DNA forensic techniques for identifying poached guanacos (Lama guanicoe) in Chilean Patagonia. J. Forensic. Sci. 54: 1073-1076.

Meier D and Merino ML (2007). Distribution and habitat features of southern pudu (Pudu puda Molina, 1782) in Argentina. Mamm. Biol. 72: 204-212.

Moore SS, Byrne K, Berger KT, Barendse W, et al. (1994). Characterization of 65 bovine microsatellites. Mamm. Genome 5: 84-90.

Oliveira EJF, Garcia JE, Barbanti JM and Betioli EP (2008). Development and characterization of microsatellite loci in the marsh deer (Blastocerus dichotomus Cervidae). Conserv. Genet. 10: 1505-1506.

Orozco-terWengel P, Chiari Y, Vieites DR and Pedrono M (2013). Isolation and characterization of six polymorphic microsatellite loci for the Malagasy spider tortoise, Pyxis arachnoides and cross-amplification in Pyxis planicauda. Amphibia-Reptilia 34: 125-128.

Peakall R and Smouse PE (2006). GenAlEx 6: genetic analysis in Excel. Population genetic software for teaching and research. Mol. Ecol. Notes 6: 288-295.

Povilitis A (1998). Characteristics and conservation of a fragmented population of huemul Hippocamelus bisulcus in central Chile. Biol. Conserv. 86: 97-104.

Røed KH and Midthjell L (1998). Microsatellites in reindeer, Rangifer tarandus, and their use in other cervids. Mol. Ecol. 7: 1773-1776.

Serret A (1992). Distribución actual del huemul (Hippocamelus bisculus) en la República Argentina. Boletín Técnico No. 1. Fundación Vida Silvestre Argentina. Proyecto Huemul, Buenos Aires.

Shafer ABA, Corti P, Coltman DW and Marín JC (2012). Development of eight microsatellite loci from the endangered 
huemul (Hippocamelus bisulcus) and cross-species amplification in six other ungulate species. Conserv. Genet. Resour. 4: 571-573.

Sikes RS, Gannon WL and Animal Care and Use Committee of the American Society of Mammalogists (2011). Guidelines of the American Society of Mammalogists for the use of wild mammals in research. J. Mammal. 92: 235-253.

Silva-Rodríguez EA, Verdugo C, Aleuy OA and Sanderson JG (2010). Evaluating mortality sources for the vulnerable pudu Pudu puda in Chile: implications for the conservation of a threatened deer. Oryx 44: 97-103.

Slate J, Coltman DW, Goodman SJ, MacLean I, et al. (1998). Bovine microsatellite loci are highly conserved in red deer (Cervus elaphus), sika deer (Cervus nippon) and Soay sheep (Ovis aries). Anim. Genet. 29: 307-315.

Vaiman D, Osta R, Mercier D, Grohs C, et al. (1992). Characterization of five new bovine dinucleotide repeats. Anim. Genet. 23: 537-541.

Wemmer C (1998). Deer: Status Survey and Conservation Action Plan. IUCN/SSC Deer Specialist Group, IUCN, Gland.

Wilson GA and Strobeck C (1999). The isolation and characterization of microsatellite loci in bison, and their usefulness in other artiodactyls. Anim. Genet. 30: 226-227.

Wilson GA, Strobeck C, Wu L and Coffin JW (1997). Characterization of microsatellite loci in caribou Rangifer tarandus, and their use in other artiodactyls. Mol. Ecol. 6: 697-699. 